\title{
Pemahaman Hadis Kepemimpinan Quraish: Studi Komparasi Ibnu Taimiyyah dan Ibnu Khaldūn
}

\author{
Mila Melyani \\ UIN Sunan Gunung Djati Bandung; melyanimila29@gmail.com \\ *Correspondence
}

Received: 2020-07-09; Accepted: 2020-09-18; Published: 2020-09-30

\begin{abstract}
To understand a hadith we can combine between traditional science and modern scientific approach. This can be applied to the sahih hadith regarding leadership that must be from the Quraish tribe which is very problematic. Authenticity of these hadith must be carried out before analyzing and contextualizing those to this modern government system. Among the scholars who tried to understand the hadith of the Quraish leadership were Ibn Taimiyyah and Ibn Khaldūn. Both figures were experts in the socio-political field who had different social backgrounds. Ibn Taimiyyah stream of thought, especially in various political, state, and government issues, also seems to be closely interwoven with the national and religious context. Ibn Khaldūn had a descendant of one of the companions of the Prophet Muhammad. Who was named Wail Ibn Hujr. Ibn Khaldūn lived in complex political and tribal conditions. He is a significant figure who emerged when the Islamic world became small states due to fragmentation. Ibn Taimiyyah understood the meaning of the hadith of Quraish leadership by using the Mașlahah mursalah method and Ibn Khaldūn using the Sociological approach method.
\end{abstract}

Keywords: Leadership; Quraysh; Ibn Taimiyyah; Ibn Khaldūn; Hadith.

\begin{abstract}
Abstrak: Memahami sebuah hadis tidak harus terpaku dengan keilmuan yang tradisional, bisa juga menggunakan pendekatan keilmuan modern, seperti halnya hadis shahih mengenai kepemimpinan itu harus berada pada suku Quraish sangat problematis. Dalam satu sisi hadis shahih wajib diamalkan akan tetapi pihak lain hadis tersebut sangat sulit diterapkan dalam sistem pemerintahan zaman modern ini. diantara ulama yang berusaha memahami hadis kepemimpinan Quraish tersebut ialah Ibn Taimiyyah dan Ibnu Khaldūn, kedua tokoh tersebut merupakan ahli di bidang sosial politik yang memiliki latar belakang sosial yang berbeda. Ibnu Taimiyyah dikenal juga sosok da'i yang tangguh serta memahami berbagai permasalahan pada masanya dengan ilmunya. arus pemikirannya terutama dalam berbagai permasalahan politik, kenegaraan dan pemerintahan, juga terkesan terjalin erat dengan konteks kebangsaan dan keagamaan.Ibnu Khaldūn memiliki keturunan salah seorang sahabat Rasulullah SAW yang bernama Wail Ibnu Hujr. Ibnu Khaldūn hidup dalam kondisi politik dan kesukuan yang rumit. Pada masa itu beliau berpindah-pindah antara Maroko, Andalusia dan Mesir adalah tempat beliau wafat. Ia merupakan sosok agung yang muncul ketika dunia Islam menjadi negaranegara kecil karena terpecah-belah. Ibnu Taimiyyah memahami makna hadis kepemimpinan Quraish dengan menggunakan metode Mașlahah mursalah dan Ibnu Khaldūn menggunakan metode pendekatan Sosiologis.
\end{abstract}

Kata Kunci: Kepemimpinan; Quraish; Ibn Taimiyyah; Ibn Khaldūn; Hadis. 


\section{Pendahuluan}

Sudah empat belas abad lamanya syari'at Islam mengatur kehidupan umat Islam, bukan hanya masalah tauhid, ibadah akan tetapi syariat hukum serta sistem hukum pemerintahan dalam Islam telah memerintahkan kepada kaum muslim agar mendirikan negara dan pemerintahan, beserta yang memerintah berdasarkan hukum-hukum Islam, agar tercipta nya negara yang baldah țayibah wa rabb ghafūr(Adhayanto, 2011; Iqbal, 2016; Yunus, 2015). tentu pasti sangat penting untuk memilih seorang pemimpin. Pemimpin harus adil dan melayani masyarakat untuk kemashlahatan umat (Rangkuti, 2017). sebagai mana firman Allah SWT :

"Dan (menyuruh kamu) apabila menetapkan hukum di antara manusia supaya kamu menetapkan hukum yang adil” (Q.S An Nisā : 48).

Dari ayat tersebut bahwa penting untuk kita memilih pemimpin yang adil serta yang akan membawa kesejahteraan umat. Allah SWT menciptakan manusia tidak lain adalah untuk beribadah kepada-Nya, bentuk ibadah kita selaku umat Islam adalah dengan menjalankan perintah Allah dan menjauhi segala apa yang dilarang, dengan peraturan dan pedoman yang harus kita yakini dan dijalankan sebagai seorang Muslim. Islam mengatur hubungan manusia dengan Allah, manusia dengan manusia, serta manusia dengan seluruh makhluk ciptaan Allah SWT (Harahap, 2018). Sehingga untuk mengatur itu semua harus ada seorang peminpin, memilih seorang pemimpin sangat penting dalam kehidupan bernegara penting untuk memilih seorang pemimpin (Sholihin, 2008).

Pada tahun 1999 karya J. Suyuthi Pulungan, dalam bukunya yang berjudul fikih siyasah beliau melakukan kajian kesejarahan pemikiran politik islam dari pemikiran politik khawarij sampai pemikiran politik Sunni zaman klasik dan pertengahan, dalam Buku ini membahas mengenai hadishadis kepemimpinan Quraish namun hanya sedikit pembahasan nya dan beberapa kutipan mengenai pemikiran Ibnu Taimiyah karena membahas mengenai prinsip-prinsip ummah (S. Pulungan, 1999, hlm. 226). penelitian mengenai kepemimpinan Quraish terdapat dalam skripsi Hasisul Ulum di Institut Agama Islam Negeri Walisongo Semarang Mengenai Studi Pemahaman Ibnu Taimiyyah Tentang Hadis Kepemimpinan Quraish. Tulisan ini membahas mengenai pemikiran Ibnu Taimiyyah mengenai hadis kepemimpinan Quraish dari mulai pemikiran, latar belakang pemikiran sosial dan politik nya, namun dalam tulisan ini tidak menjelaskan pengertian pemimpin menurut para tokoh muslim dan tokoh barat dan tidak melakukan studi komparasi dengan Ibnu Khaldūn (Ulum, 2012). peneltian lain yang terdapat pada jurnal Jurnal Politik Profetik karya Muh Ilham Mengenai Konsep Așabiyyah dalam Pemikiran Politik Ibnu Khaldūn, Vol 04 No1. Uin Alauddin Makassar. Dalam jurnal nya itu menjelaskan mengenai elaborasi pemikiran Ibnu Khaldūn, mengenai negara dan sedikit menjelaskan mengenai syarat pemimpin Quraish namun tidak membahas lebih detail redaksi hadis dan makna hadis mengenai kepemimpinan Quraish, hanya menjelaskan syarat-syarat nya saja (Ilham, 2016, hlm. 6). selain itu sebuah Skripsi Hari Putra Z mengenai Pemahaman Hadis Kepemimpinan Quraish Universitas Syarif Hidyatullah Jakarta. Namun skripsi ini tidak membahas lebih rinci dan tidak spesifik membahas pemikiran tokoh Ibnu Taimiyah dan Ibnu Khaldūn (Putra Z, 2018). dan juga Pada tahun yang sama terdapat Skripsi Alba Roma Triwijaya mengenai Analisis Perbandingan Corak Pemikiran Etika Politik Ibnu Taimiyyah dan Ibnu Khaldūn. Universitas Raden Intan Lampung Tahun 2018. dalam skripsi ini menjelaskan perbedaan etika politik serta persamaan nya menurut Ibnu Taimiyah dan Ibn Khaldūn namun sedikit membahas dan mengkutip mengenai kepemimpinan Quraish, tidak membahas perbandingan hadis kepemimpinan Quraish menurut Ibnu Taimiyah dan Ibnu Khaldūn karena lebih banyak membahas etika berpolitik nya (Triwijaya, 2018).

Penelitian seblum-Nya yang belum dibahas oleh para peneliti yang lain ialah dari segi metode pemahaman hadis kepemimpinan Quraish yang digunakan tokoh Ibnu Taimiyyah dan Ibnu Khaldūn serta mengenai konsep negara menurut Ibnu Taimiyyah dan Ibnu Khaldūn. Metode yang digunakan dalam penelitian ini adalah metode analisis deskriptif dengan menggabungkan kedua pemikir islam yaitu Ibnu Taimiyyah dan Ibnu Khaldūn. Membandingkan sharah kitab minhāj aj al-Sunnah alNabawiyah fi Naqdi Kalami al-Syi'ah wal Qadariyah dengan dan kitab Muqaddimah Ibnu Khaldūn, menggunakan dengan pendekatan ilmu fiqh, ilmu sosiologi dan syarah hadis. 


\section{Analisis Pemikiran Hadis Kepemimpinan Quraish}

\section{Hadis Kepemimpinan Quraish Menurut Ibnu Taimiyyah}

\section{Metode Pemahaman Ibnu Taimiyyah terhadap Hadis Kepemimpinan Quraish}

Ibnu Taimiyyah semasa hidupnya Dalam berbagai kesempatan ia sering melontarkan ide yang bertentangan dengan pendapat para penguasa ataupun sebagian besar masyarakat kebanyakan (Cahyadi, 2015; Purwanto, 2018), beliau ialah penentang keras terhadap setiap bentuk khurafat dan bid'ah atau inovasi terhadap agama (Swito, 2011; Zarkasyi, 2013), dengan sikap yang demikian beliau dimusuhi oleh banyak ulama ahli hukum dan beliau sering menentang arus sehingga ia berkali-kali dimasukkan ke dalam penjara karena tidak mematuhi perintah penguasa (Sucipto, 2013; Syukkur, 2019). Raja Nasir tidak dapat melindunginya lagi kemudian enam bulan setelah dipenjara Ibnu Taimiyyah dibebaskan, masalah tersebut belum juga reda karena anggota-anggota dewan menyebarkan fitnah yang akhirnya diberi tambahan hukuman penjara lima bulan terhadap Ibnu Taimiyyah pada tahun $1320 \mathrm{M}$ (Munawir, t.t., hlm. 81).

Ibnu Taimiyyah mengartikulasikan pandangan, ide serta sikap nya, bahkan di dalam menentukan metode pemahaman hadis kepemimpinan Quraish. Di antara beberapa faktor yang mempengaruhi pemikiran Ibnu Taimiyyah pada respon nya terhadap hadis kepemimpinan Quraish ialah: Pertama: faktor historis, dikarenakan Ibnu Taimiyyah ialah seorang pengikut Madhab Hambali yang coraknya salafisme (Ardiansyah, 2013; Hamang, 2010). Salafisme itu mempunyai arti tipologi tekstualisme dalam memahami teks keagamaan, Kedua: faktor sosial politik, realitas politik yang mempunyai pengaruh yang signifikan kepada pemahaman Ibnu Taimiyyah dalam merespons hadis kepemimpinan Quraish (Triwijaya, 2018). Dengan demikian dunia Islam harus memiliki pemimpin negara yang kuat dan berwibawa yang mampu mengembalikan kekuatan dan kekuasaan umat Islam. Ia melihat berbagai macam ancaman disentegrasi umat Islam, baik itu dari dalam Islam ataupun dari luar Islam. Jika dilihat dari dalam perpecahan umat Islam dan pengelompokkan kekuatan politik, semasa Ibnu Taimiyyah hidup, kelompok Syi'ah selalu berusaha menjatuhkan kekuasaan kepala negara. Ibnu Taimiyyah mendapatkan tempat tersendiri didalam rumusan politiknya yaitu dalam kitab Minhāj al-Sunnah fì Naqd Kalām al-Shi'ah wa al-Qadariyyah yang khusus delapan jilid yang menolak pandangan-pandangan Syi'ah dan Khawarij, Ia mengatakkan bahwa mereka merupakan duri dalam daging di tubuh umat Islam (Ibnu Taimiyyah, t.t., hlm. 190). Jika dilihat dari latar belakang sosio-historis syarat kepemimpinan Quraish telah banyak mendapatkan perhatian di kalangan para ulama sejak pertama hijriyah termasuk Ibnu Taimiyyah sebagai tokoh yang memiliki ilmu yang luas dan mendalam, baik dalam bidang al-Qur'an, hadis, fikih, ataupun aqidah dan dengan latarbelakang politiknya. Pemahamannya mengenai syarat suku Quraish tidak terlepas dari keadaan suku Quraish pada masanya karena setelah kekuasaan Bani Abbas hancur pada tahun 1258M, kekuatan suku Quraish tidak berpengaruh lagi. Ketiga, Ibnu Taimiyyah sangat menghargai akal, namun akal yang dibimbing oleh agama. Menurut Ibnu Taimiyyah kekuasaan ialah mandat tuhan yang diberikan kepada hambahamba yang terpilih("Pemikiran Politik Sunni, Syiah, Khawarij Dan Mu'tazilah - Kompasiana.Com," t.t.). Dengan demikian Ibnu Taimiyyah berpendapat hukum harus ditegakkan oleh negara, kemudian negara harus berjalan diatas keadilan hukum, sehingga perlu adanya ketentuan yang defenitif yang mengatur tugas serta ruang gerak masing-masing dalam wujud hukum yang berlaku secara objektif (Anjum, 2012; Kayadibi, 2018).

Ibnu Taimiyyah mengambil peranan sebagai pengontrol terhadap peristiwa yang ada. Ibnu Taimiyyah mengkritik teori syi'ah mengenai Imamah pada kitab yang menjadi rujukan utama pada penelitian ini yaitu Minhāj al-Sunnah al-Nabawiyyah al-syi'ah wa al-Qadariyah, konsep Syi'ah mengenai Imamah menurut Ibnu Taimiyyah bahwa Syiah tidak memiliki dasar dalam al-Qur'an ataupun Hadis dan akal sehat, Ibnu Taimiyyah menyebutkan bahwa Imamah merupakan biang keladi perpecahan serta kelemahan umat Islam, dikarenakan Syi'ah sendiri tidak pernah sepakat dalam kepemimpinan seorang Imam. Ibnu Taimiyyah tidak memandang institusi imamah sebagai kewajiban syariah, akan tetapi hanya kebutuhan praktis saja (Haris \& Rahim, 2017). 
Ibnu Taimiyyah menerima apa adanya hadis mengenai kepemimpinan Quraish dengan sesuai teks hadis tersebut karena hadis tersebut ialah hadis yang shahih, Penerimaan Ibnu Taimiyyah mengenai kepemimpinan Quraish bukan berarti menolak kepemimpinan dari kelompok suku yang lain, dikarenakan menurut pemahamannya syarat Quraish itu bukan termasuk syarat keharusan untuk pemimpin. Beliau menerima hadis terhadap berbagai jenis kepemimpinn yang dimaknai sesuai arti literatal nya. akan tetapi Ibnu Taimiyyah tidak mengisyaratkan menyebutkan keturunan Quraish sebagai salah satu syarat keharusan (in'iqäd) artinya pemahaman tekstualnya tidak serta merta menjadikan Quraish sebagai satu-satunya syarat keharusan (in'iqäd) (J. S. Pulungan, t.t., hlm. 258). dalam kepemimpinan. Hal ini dapat dilihat dari penerimaan Ibnu Taimiyyah atas kepemimpinan bukan dari suku Quraish, bahkan kepemimpinan budak habsyī yang berkulit hitam, selagi ia memimpin berdasarkan petunjuk al-Kitāb dan al-Sunnah (Ibn Taimiyyah, t.t., hlm. 163-165).

Cakupan wilayah implementasi hadis kepemimpinan suku Quraish adalah pada kepemimpinan pusat, atau setingkat khaliffah, tidak diberlakukan untuk wilayah-wilayah daerah setingkat gubernur dan sejenisnya. Sehingga boleh mengangkat seorang gubernur yang bukan berasal dari suku Quraish asalkan dia seorang yang memiliki potensi yang lebih maslahat, kualitas dan memiliki kapabilitas dalam hal kepemimpinan. Sebagaimana menurut Ibnu Taimiyyah pengangkatan Sālim oleh khalīfah Umar bin Khattāb mungkin hanya sebagai pejabat setingkat gubernur, atau hanya sebagai pelaksana tugas pejabat yang ada yang tentunya disesuaikan dengan kualitas dan kapabilitas Sālim. Dapat dilihat dari rujukan kitab Ibnu Taimiyyah yang lain bahwa yang lebih maslahat ialah yang paling utama, sebagaimana dalam kitabnya yakni:(Ibn Taimiyyah, t.t.-a, hlm. 17)

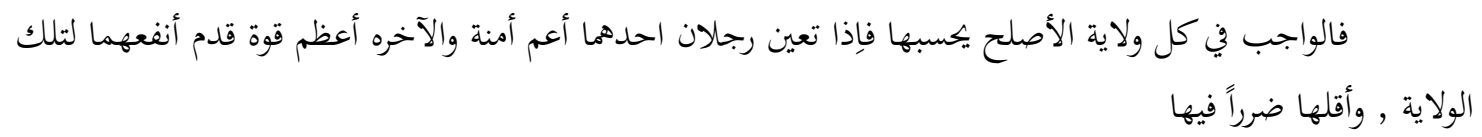

Dikarenakan Ibnu Taimiyyah lebih menekankan bahwa kepemimpinan Quraish bukan lah suatu keharusan, jika ada yang lebih memiliki kulitas sebagai pemimpin dalam artian lebih maslahat maka ialah dapat menduduki jabatan tersebut. Dengan demikian bahwa pemahaman Ibnu Taimiyyah mengenai hadis kepemimpinan Quraish ialah menggunakan metode mașlahah mursalah yang terdiri dari dua kata yang berhubungan dalam bentuk sifat mauṣuf dalam bentuk khusus yang menunjukkan dari al-mas\}lahah, mengenai arti mașlahah secara bahasa al-Mursalah ialah isim maf'ul atau objek dari fi'il maḍi atau kata dasar dengan bentuk thulasi atau kata dasar yang tiga huruf, yaknidengan penambahan alif di awal, sehingga menjadi ارسل yang artinya secara bahasa ialah terlepas atau bebas, disini jika dihubungkan dengan kata al-mas\}lahah maksudnya ialah terlepas atau bebas dari keterangan yang menunjukan boleh atau tidak bolehnya dilakukan (Zulbaidah, 2016, hlm. 133), menurut Abdul al-Wahab al-Khallaf mas\}lahah mursalah ialah maslahat yang tidak ada dalil syara' datang untuk mengakui atau menolaknya (Zulbaidah, 2016, hlm. 134). kemaslahatan sebagaimana firman allah yang berbunyi :

$$
\text { وَمَا أَرْسَنَنَاكَ إِلَّاَ رَمْةَة لِلْعَالَمِينَ }
$$

"Tidaklah semata-mata Aku mengutusmu (Muhammad) kecuali untuk kebaikan seluruh alam" (Q.S al-Anbiya: 107)

Pada masa yang akan datang permaslahan kehidupan manusia akan terus menerus berkembang sangat pesat. Permasalahan tersebut harus dihadapi oleh umat Islam yang menuntut adanya jawaban penyelesaian tersebut dari segi hukum. Seluruh persoalan tersebut tidak akan teselesaikan jika hanya menggunakan pendekatan atau metode yang lama, yang digunakan ulama-ulama terdahulu. Karena akan menghadapi kesulitan menemukan dalil untuk mendudukan hukum dari permasalahan yang muncul dan akan menghadapi juga persoalan yang rasional dapat dinilai baik buruknya untuk 
menetapkan hukumnya. Dengan demikian untuk mencari solusi mașlahah mursalah dapat dijadikan alternatif sebagai dasar untuk memahami permaslahan yang ada pada saat ini.

Pemahaman Ibnu Taimiyyah mengenai kepemimpinan Quraish menggunakan metodologi mașlahah mursalah dikarenakan kualifikasi nya seorang pemimpin ialah dua yakni al-quwwah dan alamānah, namun karena sulit dijumpai seorang yang memiliki kriteria tersebut, maka ambilah yang lebih maslahat bagi umatnya, Sebagaimana kutipan dalam kitabnya siyasyah al-shar'iyyah fị Iṣlahi Rāi wa al-Ra'iyyah karya Ibnu Taimiyyah, sebagai berikut:

$$
\begin{aligned}
& \text { فان الو لا ية لها ركنان : القوة و الأمنة كما قال تعلى : إنّ خير من استأجرت القويُ الأمنة (القصص: 26) } \\
& \text { وقال صاحب مصر ليوسف عليه السلام : إنّك اليوم لدينا مكين أمينٌ (يوسف: 54) وقال تعلى في صفة جبريل : (إنّه }
\end{aligned}
$$

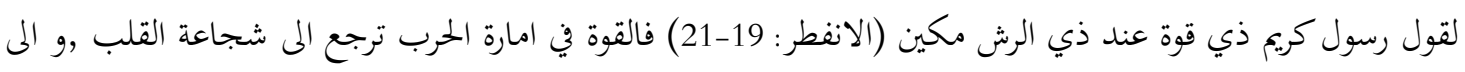

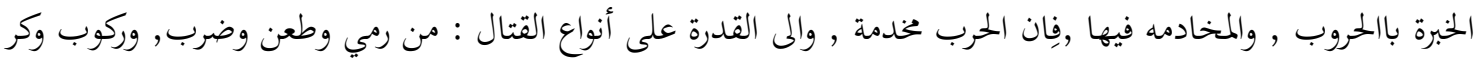

وفرِّ, ونو ذلك كما قال الله تعلى(Ibn Taimiyyah, t.t.-a, hlm. 15).

Maka hendaklah dipilih pemimpin yang paling maslahat atau sesuai menurut kapasitasnya, sesungguhnya untuk menempti sebuah kedudukan pasti harus memenuhi dua kriteria ini yaitu alquwwah dan al-amānah, sebagai mana firman Allah SWT." Karena sesungguhnya orang yang paling baik untuk kamu ambil untuk (bekerja kepada kita) adalah orang yang kuat lagi dipercaya"(Q.S alQhasas: 26). Seorang pemimpin mesir berkata kepada Nabi Yusuf a.s, "Sesungguhnya kamu mulai hari ini menjadi seorang yang berkedudukan tinggi lagi dipercaya pada sisi kami",(Q.S Yusuf: 54). Ketika menjelaskan sifat malaikat jibril, Allah SWT berfirman" Sesungguhnya al-Qur'an itu benar-benar firman Allah yang dibawa oleh utusan yang mulia (malaikat jibril), yang mempunyai kedudukan tinggi di sisi Allah SWT. sang pemilik Arsy yang ditaati di sana (di alam malaikat) lagi dipercaya (Q.S al-Takwir: 19-21).

$$
\begin{aligned}
& \text { اجتماع القوي والأمنة في الناس قليل, ولذذا كان عمر بن الخطب يقول: اللهم أشكو اليك جدل الفاجر ووعجز } \\
& \text { الثقة .فالوا جب في كل ولاية الأصلح يحسبها فإِا تعين رجلان احدهما أعظم أمانة والآخر أعظم قوة قدم أنفعهما لتلك فيك } \\
& \text { الولاية , وأقلها ضرراً فيها , فيقدم في امارة الحروب الرجل القوي الشجاع وان كان فيه فجور فيها غلى الرجل الضعيف }
\end{aligned}
$$

العاجز (Ibn Taimiyyah, t.t.-a, hlm. 17).

Akan tetapi pada kenyatanya yang menunjukan bahwa orang yang memiliki sifat al Quwwah dan al-Amanāh itu sangat sedikit. Pada suatu hari ketika Umar al-Khatab r.a, beliau berdoa," Yallah aku mengadu kepada-Mu karena kekuatan para pembuat dosa dan kelemahan orang yang dapat dipercaya." Dengan demikian, pemilihan ataupun pengangkatan pemimpin untuk menempati daerah tertentu haruslah disesuaikan dengan kondisi serta kebutuhan di daerah itu sendiri. jika terjadi hal yang demikian maka kepala negara itu dapat diangkat menurut kriteria yang paling maslahat untuk konteks jabatan yang akan dijalankanya. Apabila ada dua orang yang satu lebih unggul sifat amanahnya, namun yang lain lebih unggul dari sifat quwwah nya, maka yang di dahulukan ialah orang yang paling bermanfaat diantara keduanya bagi jabatan itu dan yang paling sedikit madarat nya. Sebagaima bagi panglima perang, yang didahulukan ialah orang yang kuat dan pemberani meskipun memiliki sifat nya jelek, atas orang yang lemah dan penakut meskipun amanah. Seperti jawaban Imam bin Hanbal ketika ditanya perihal dua orang yang dapat dijadikan panglima perang, yang satu kuat, tapi memiliki sifat jelek, dan yang satu shaleh tapi lemah, manakah diantara keduanya yang patut dijadikan panglima perang?"Ia menjawab: “ adapun orang yang memiliki sifat jelek tetapi kuat, maka kekuatannya akan bermanfaat bagi umat Islam, sementara kejelekannya hanya untuk dirinya sendiri, sedangkan orang yang shalih tapi lemah, maka ke shalihannya hanya untuk dirinya sendiri, sementara 
kelemahannya akan berakibat buruk bagi umat Islam. Maka yang tepat untuk dijadikan panglima perang ialah orang yang kuat meskipun bersifat jelek.

\section{Konsep Kepemimpian Menurut Ibnu Taimiyyah}

Kepemimpinan Ibn Taimiyyah itu menggunakan kata Imāmah, Ibnu Taimiyyah berpendapat bahwa kepemimpinan itu tidak ada dasar dalam al-Qur'an, sebagaimana kutipan dalam kitabnya: (Ibn Taimiyyah, t.t.-b, hlm. 163-165).

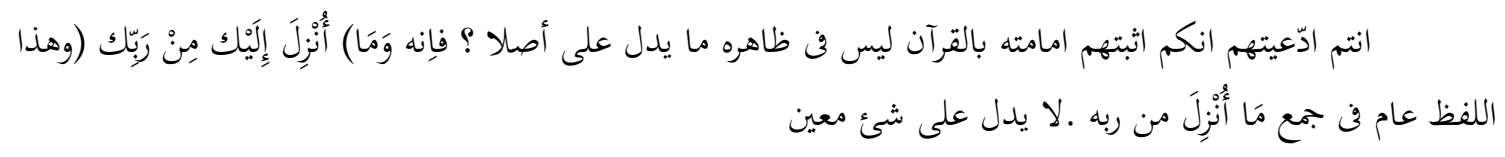

Ibnu Tamiyyah menyerang kelompok Sunni dan Syi'ah, bahwa mereka tidak ada dasar dalam alQur'an dan al-Sunnah mengenai teori Imamah dan Ibnu Taimiyyah menyebutkan bahwa ke khaliffahan tidak mempunyai landasan konstitusional dari al-Qur'an, memang benar adanya bahwa al-Qur'an secara khusus menjelaskan kebutuhan manusia terhadap pemerintahan, namun al-Qur'an dan alSunnah tersebut tidak menjelaskan secara detail keputusan konstitusional pemerintahan Islam. Dengan demikian mengenai keputusan konstitusional yang melandasi teori khilāfah tidak terdapat dalam al-Qur'an dan al-Sunnah.

Ibnu Taimiyyah menggunakan pemikiran Theokrasi dan Nomokrasi. Theokrasi ialah bentuk pemerintahan yang berada dalam cengkraman kekuasaan Tuhan yaitu pemerintahan yang mengakui Tuhan sebagai penguasa yang mutlak dalam berbagai tata pergaulan masyarakat dan menerima wahyu yang telah ditafsirkan oleh para wakil Tuhan sebagai dasar negara atau masyarakat, Khadduri berpendapat bahwa Theokrasi ialah suatu pemerintahan yang menganggap Tuhan sebagai raja, sedangkan Nomokrasi merupakan sistem pemerintahan yang berdasarkan pada hukum atau undangundang yang resmi yakni aturan hukum dalam masyarakat. Dengan demikian pemikiran Ibnu Taimiyyah dalam sistem pemerintahan itu bersifat nomokratik bahwa seorang pemerintahan yang berkuasa merupakan hukum yang paling tinggi yang menggantikan segala bentuk kekuasaan yang lain, akan tetapi hakikat dan sekup hukum tersebut membedakan pemerintahan Islam dengan berbagai nomokrasi historis karena memiliki istilah tersendiri (Jindan, 1995, hlm. 70).

Konsep Ibnu Taimiyyah mengenai kebutuhan manusia kepada negara didasarkan pada akal dan hadis, pendapat yang sifatnya rasional terletak kepada kebutuhan yang mencakup seluruh manusia untuk bergabung, bekerja sama menikmati berbagai manfaat kepemimpinan tanpa memperdulikan apakah menganut agama atau tidak. Pendapat rasionalnya itu dikuatkan oleh landasan dari hadis. Menurut Ibnu Taimiyyah perlunya pemerintahan praktek pengukuhan pemerintahan harus dianggap sebagai tugas agama yang harus ditaati seluruh umat Muslim. Istilah Daulah atau negara tidak dijelaskan dalam al-Qur'an ataupun al-Sunnah, akan tetapi unsur-unsur esensial yang menjadi dasar bernegara terdapat dalam al-Qur'an dan al-Sunnah. sebagaimna yang perumpamaan yang Ibnu Taimiyyah sebutkan bahwa al-Qur'an menjelaskan seperangkat prinsip-prinsip yang dapat ditafsirkan dengan adanya tata tertib sosio-politik unuk tegaknya sebuah negara yang termasuk di dalamnya ialah keadilan, peradilan, kepatuhan, kehakiman dan persaudaraan. Di dalam al-Qur'an dapat ditemukan hukum-hukum yang sifatnya umum ataupun yang secara langsung menyinggung permasalahan pembagian harta rampasan perang untuk menciptakan perdamaian antar sesame (Jindan, 1995, hlm. 46). Pemaparan Ibnu Taimiyyah dalam karyanya al siyasyah, merupakan gambaran yang cukup lengkap mengenai negara hukum. Yang terdiri dari empat hal yaitu: Pertama, syari'ah ialah sumber hukum yang paling tinggi. Semua bentuk tindakan serta perbuatan manusia harus mempunyai landasan setidaknya sesuai dengan syari'ah. Apabila terjadi perbedaan pendapat atau konflik, maka cara menyelesaikannya harus merujuk pada ketentuan syari'ah. Kedua, pengaplikasian hukum diberlakukan tanpa pandang bulu, baik itu dari orang yang terhormat atau orang yang hina. Ketiga, untuk menindak pihak yang diduga melakukan pelanggaran, dibuhkan bukti yang aktual, dengan demikian penerapan hukuman tidak dapat dilakukan dengan sewenang-wenang. Keempat, 
memelihara manusia dari ancaman-ancaman serta hak-hak asasi manusia seperti hak kehidupan, kehormatan pribadi, hak mengajukan pendapat keberadaanya dijamin oleh syari'ah.

Adapun mengenai lembaga lembaga pemerintahan, Ibnu Taimiyyah tidak merincikan lembaga nya karena yang terpenting sesuai dengan syariat Islam, namun penulis merangkum pemahaman Ibnu Tamiyyah menjadi dua lembaga yang terpenting yakni, lembaga (mentri) keuangan dan pengadilan (hakim): lembaga keuangan dan lembaga peradilan.

Syarat-syarat Pemimpin menurut Ibnu Taimiyyah sangat memperhatikan klasifikasi calon kepala negara, Pengangkatan pemimpin negara mutlak harus dilaksanakan, maka dari itu perlu dilakukan seleksi seselektif mungkin kepada calon kandidat pemimpin. Beliau berpendapat orang yang pantas untuk menjdai kepala ngara ialah orang yang memiliki al-Quwwah (kekuatan atau otoritas) serta alAmānah (orang yang dipercaya) (J. S. Pulungan, t.t., hlm. 258). Dalam kitab Minhāj al-Sunnah alNabawiyyah al-syi'ah wa al- Qadariyah Ibnu Taimiyyah berpendapat bahwa:

$$
\begin{aligned}
& \text { ومنها : أن النبي ص.م لما مات , وطلب بعض الأنصار أن يكون منهم أمير ومن المهاجرين أمير فأُنكر ذلك }
\end{aligned}
$$

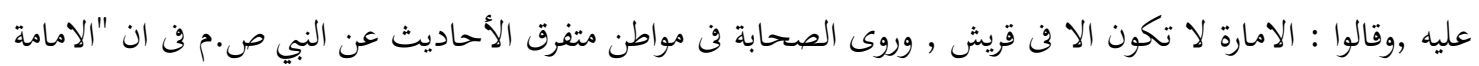

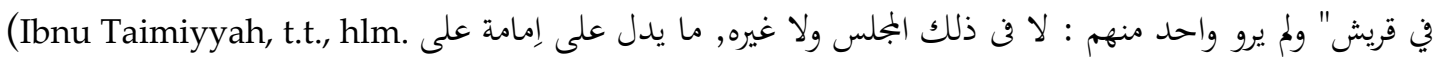

Beliau hanya menegaskan dua syarat untuk menjadi pemimpin negara yakni kejujuran al-amānah dan al quwwah (kewibawaan) atau kekuasaan. Kedua hal tersebut merupakan syarat yang mutlak yang harus dipenuhi, dengan kedua syarat ini maka akan terciptanya keadilan dalam masyarakat inilah yang menjadi tujuan- tujuan utama dalam syariah Islam (Ibn Taimiyyah, 1999, hlm. 14). Karena Allah SWT mewajibkan amar ma'rūf dan nahi munkar, dengan demikian bahwa amar ma'rūf dan nahi munkar itu tidak akan mungkin dapat terwujudkan dengan baik tanpa adanya al-Quwwah (otoritas) kekuasaan dan imarah (kepemimpinan)(Ibn Taimiyyah, 1999, hlm. 157).

Al-Quwwah ialah kekuasaan dalam setiap wewenang dan setiap kekuasaan itu bergantung jenisnya, jika kekuasaan dalam kepemimpinan perang ialah keberanian, kemahiran dalam mengatur siasat serta menyusun strategi perang dan memiliki kehandalan menguasai berbagai jenis pelaratan perang. Sebagaimana Allah SWT. berfirman:

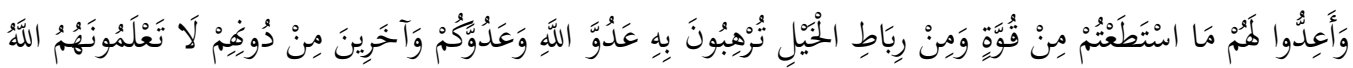

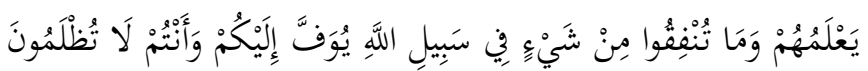

“Dan siapkanlah untuk menghadapi mereka kekuatan apa saja yang kamu mampu dan dari kudakuda yang ditambat untuk berperang yang dengan persiapan itu kamu menggetarkan musuhmusuh Allah." (Q.S al-Anfāl: 60).

Dengan demikian bahwa pemimpin itu harus memiliki kekuatan untuk berperang dengan kekuatan apa saja yang dapat mengalahkan musuh baik itu memanah, berkuda, berpedang, bahkan harus pemimpin harus pandai menyusun strategi. Sedangkan kekuasaan dalam pemerintahan ialah sikap adil yang dicontohkan oleh al-Qur'an dan al-Sunnah. Yang demikian itulah kekuasaan otoritas.

Sementara amanah kaitannya dengan rasa khauf (takut) kepada sang pencipta yakni Allah SWT, tidak menjadikan transaksi jual beli ayat-ayat Nya serta menghindari takut kepada sesama makhluk (manusia). Tiga hal inilah yang Allah SWT jadikan sebagai asas dalam setiap pemerintahan untuk mengtur umat manusia. Sebagaimana Allah SWT. berfirman:

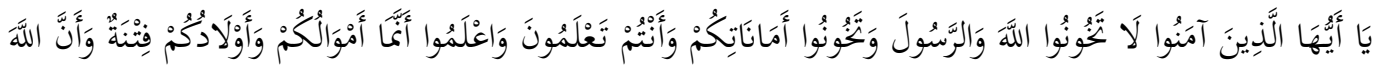

$$
\begin{aligned}
& \text { عِنْدَهُ أَجْرِ عَظِيمُ }
\end{aligned}
$$


"wahai orang-orang yang beriman, janganlah kamu sekalian berkhianat kepada Allah SWT, Rasul dan berkhianat pada amanat-amanat yang telah diberikan kepadamu, padahal kamu sekalian mengetahui. Dan ingatlah bahwa harta-hartamu dan anak-anakmu iti dapat menjadi fitnah bagi kamu sekalian dan sesungguhnya di sisi Allah ada pahala yang besar" (Q.S al-Anfāl : 27).

Dalam suatu wilayah kekuasaan membutuhkan adanya sifat amanat orang yang lebih dipercaya yang pantas menduduki tempat sebagai pemimpin seperti para pejabat keuangan dan sejenisnya. Adapun kriteria yang harus dipenuhi oleh pengawas keuangan ialah mempunyai sifat amanah yang kuat, sebagaimana menurut Ibnu Taimiyyah: (Ibn Taimiyyah, t.t.-a, hlm. 28).

$$
\text { . الاموال ونخوها , فاما استخراجها وحفظها, فلا بد فيه من قوة وامانة... }
$$

Dengan kekuatannya atau ketegasannya dapat menghimpun dana seperti zakat, pajak dan sebagainya sedangkan dengan kejujurannya dapat menjaga dan mengawasi pelaksanaan penggunaan dana yang sudah terhimpun.

Sedangkan dalam struktur peradilan lebih di utamakan yang berilmu, bertaqwa dalam bidang ini, apabila terdapat yang lebih pantas dan yang tepat menduduki lembaga ini yang satu menonjol dari segi keilmuan nya sementara yang satu lebih menonjol dari segi ketaqwaannya, untuk menentukan siapa diantara mereka yang menjabat di lembaga ini bergantung kepada kondisi yang hendak digarahlm. Sebagaimana menurut Ibnu Taimiyyah: (Ibn Taimiyyah, t.t.-a, hlm. 28)

$$
\begin{aligned}
& \text { وهكذا في سائر الولايات اذا لم تتم المصلحة برجل واحد , جمع بين عدد, فلا بد من ترجم الاصلح ,او تعدد }
\end{aligned}
$$

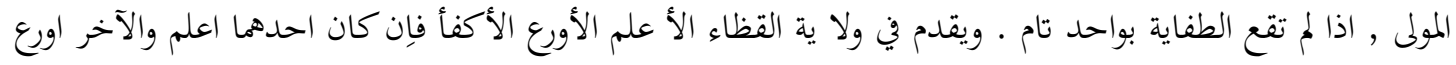

$$
\begin{aligned}
& \text { قدم فيما قد يظهر حكمه ويخاف فيه الهو ى الأروع }
\end{aligned}
$$

Apabila khawatir hawa nafsu yang berbicara dalam proses hukum yang lebih utama ialah mengangkat yang lebih bertaqwa, namun apabila timbul ke khawatiran terhadap teradinya kehancuran dalam pemutusan hukum, maka pilihlah yang berilmu.

Orang yang berilmu serta bertaqwa harus lebih diutamakan daripada yang mampu dan kuat. Karena syarat ini harus dipenuhi bila sang hakim mendapat dukungan secara luas dari instansi atau khalayak umum, karena tidak menutup kemungkinan justru yang kuat dan mampu lebih diutamakan karena badan peradilan benar-benar membutuhkan hakim yang memenuhi kriteria ini. Secara mutlak hakim seharusnya berilmu bertaqwa dan memiliki potensi. Bahkan ketiga syarat ini berlaku seluruh sektor wilayah kekuasaan. Apabila salah satu dari ketiga sifat ini tidak terpenuhi, maka akan timbul kelemahan pada segi-segi tertentu. Maksud dari kemampuan atau kekuatan disini ialah suatu cara atau taktik yang dapat mempengaruhi orang lain baik dilakukan secara kasar dengan paksaan ataupun halus. Pada prinsipnya kemampuan berdiplomasi dan ketegasan dibutuhkan dalam lembaga ini.

Maka dari itu seorang pemimpin harus benar-benar berkualitas mempunyai tanggung jawab amanah, karena pemimpin dituntut agar melaksanakan tujuan utama Syariat Islam yakni kesejahteraan umat lahir dan batin serta tegaknya keadilan dalam bermasyarakat.

\section{Hadis kepemimpinan Quraish Menurut Ibnu Khaldūn}

\section{Metode Pemahaman Ibnu Khaldūn terhadap Hadis Kepemimpinan Quraish}

Ibnu Khaldūn pernah menerima kepercayaan sebagai hakim agung untuk Mazhab Maliki, kemudian Di Kairo Ibnu Khaldūn membentuk suatu halaqah yang bertempat di Universitas al-Azhar dan memberikan kuliah hadis dan fikih Maliki dengan menerangkan teori-teori kemasyarakatan yang terdapat dalam kitab Muqaddimah. Dalam kitab ini, beliau menyebutkan berbagaimacam kendala serta penyebab tegaknya negara yang diantaranya membahas mengenai perbedaan pendapat umat Islam tentang Khilāfah. Dari mulai penamaan Khilāfatullah (khilāfah Allah) itu sudah menjadi 
perbedaan, sebagian mereka ada yang memberbolehkannya khalīfahan secara umum yang berlaku untuk seluruh umat manusia sebagaimana yang disebutkan dalam firman Allah SWT:

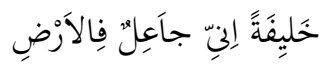

"Sesungguhnya Aku hendak menjadikan seorang khaliffah di muka bumi" (Q.S al-Baqarah : 30). Sedangkan kebanyakan ulama menolak karena pengertian ayat tersebut tidaklah seperti itu karena pada zaman Abū Bakar al-S\}iddiq beliau menolak dipanggil dengan nama tersebut seraya mengatakan," Aku bukanlah khalīfah Allah melainkan aku ialah khalīfah Rasulullah."

Setelah mengenai perbedaan penamaan Khilāfatullah kemudian permasalahan mengenai bahwa mengangkat seorang khilāfah itu apakah wajib ataukah tidak perlu. Ada yang berpendapat bahwa mengangkat seorang khalīfah itu wajib, hukum kewajiban mengangkat pemimpin dalam syariat ialah berdasarkan ijma'(kesepakatan) para sahabat tabiin. Sebagian ulama mengatakan mengangkat pemimpin ialah rasionalitas sedangkan ijma' memperkuat ketetapan akal, kepemimpinan harus ditegakkan berdasarkan akal sebab manusia harus hidup bermasyarakat dan tidaklah mungkin bagi manusia untuk hidup serta eksis sendirian tanpa membutuhkan manusia yang lain. Konsekwensi logis dari hidup bermasyarakat diantaranya ialah terjadinya konflik karena perbedaan tujuan dan kepentingan. Jika tidak ada peran pemerintah yang bertugas untuk mengendalikan hal tersebut, maka akan menimbulkan perpecahan bahkan pertumpahan darah dan pada akhirnya menyebabkan kehancuran umat manusia kemudian punahlah mereka. Ibnu Khaldūn mengatakan bahwa untuk menghilangkan konflik tersebut cukup dengan memiliki kesadaran serta pengetahuan bahwa masingmasing individu tidak boleh melakukan perbuatan zalim kepada sesama manusia (Khaldun, 2014, hlm. 340).

Sedangkan pendapat mengenai khalīfah itu sama sekali tidak penting ialah menurut kaum Mu'tazilah yaitu al-Așamm dan beberapa orang khawarij. Menurut pendapat mereka bahwa mengangkat seorang pemimpin tidaklah penting baik itu dari segi rasionalitas akal ataupun petunjuk syari'at karena menurut mereka yang wajib itu ialah menetapkan hukum dan syari'at. Apabila suatu kaum telah menerapkan sistem keadilan serta melaksanakan hukum-hukum yang berasal dari Allah SWT. maka pemmpin itu sudah tidak lagi dibutuhkan dan tidak ada pula menjadi keharusan untuk mengangkat seorang pemimpin (Khaldun, 2014, hlm. 2).

Menegakkan syariat hukum-hukum Islam merupakan kewajiban, penegakkan syariat ini tidak akan tercapai dengan baik kecuali mendapatkan dukungan fanatisme dan kekuasaan. Secara naluriah fanatisme menuntut tercapainya kekuasaan hingga kekuasaan tersebut benar-benar tercapai meskipun belum ada pengangkatan pemimpin. Jika telah ditetapkan bahwa menangkat pemimpin hukumnya wajib berdasarkan ijma', maka hal tersebut termasuk wajib kifayah, yang diserahkan kepada majelis perwakilan rakyat. Mereka berkewajiban memilih dan mengangkatnya, dan kepada seluruh masyarakat harus mematuhinya (Khaldun, 2014, hlm. 339).

Dengan demikian, latar belakang pemahaman Ibnu Khaldūn mengenai hadis kepemimpinan Quraish ialah berawal dari banyaknya perbedaan pendapat dari berbagai golongan mengenai kepemimpinan Islam. Sehingga Ibnu Khaldūn melakukan kajian mendalam mengenai arti kepemimpinan serta sistem pemerintahan dengan kualifikasi menjadi seorang pemimpin. Hadis kepemimpinan Quraish tersebut menjadi syarat yang terpenting untuk menjadi seorang pemimpin.

Metode yang dipakai Ibnu Khaldūn untuk memahami hadis kepemimpinan Quraish ialah dengan menggunakan pendekatan sosiologis, sosiologi ialah suatu kajian ilmiah mengenai kehidupan masyarakat manusia, sosiolog (ahli sosiologi) (Kahmad, 2009, hlm. 9). sistem hubungan kemasyarakatan yang menjadi pokok pembahasan sosiologi adalah hubungan kekerabatan, hubungan pergaulan, hubungan pekerjaan, hubungan formal dan informal serta hubungan lainnya (Sumaryadi, 2010, hlm. 13). Ibnu Khaldūn diketahui sebagai seorang yang merevolusikan ilmu-ilmu pengetahuan sosial dengan persfektif yang dipengaruhi oleh lingkungan serta kondisi sosial politikumat Islam pada masa itu (Husain, t.t., hlm. 36). Bagi umat Islam beliau selalau menjadi seorang yang mengurangi kebingungan negara Islam. Ibnu Khaldūn ialah satu-satunya pemikir Islam yang berusaha melihat 
kembali fenomena-fenomena, dalam analisanya mengenai kekuasaan dan negara (Muzaffari, 1994, hlm. 10)dan beliau ialah orang yang pertama kali menyadari ketidak cocokan antara ekslusivitas kesukuan dengan keuniversalan ajaran-ajaran al-Qur'an dengan memberikan suatu penjelasan teori mengenai sosiologis. Otoritas kerajaan berasal dari rasa superioritas, yang datang dari semangat kesukuan (Așabiyyah), disini terlihat bahwa ketika tata kerja dan realitas suatu kekuasaan Islami berasal dalam kontrol suatu suku, akan tetapi dalam beberapa hal, mereka bukanlah sumber-sumber legitimasi kekuasaan itu. Kekuasaan suku tersebut mengambil legitmasi dari al-Qur'an yang tentu saja lebih transeden dari pada marga atau bagian-bagian suku tersebut (Muzaffari, 1994, hlm. 35).

Ibnu Khaldūn berpendapat bahwa syarat Quraish bukanlah "harga mati" yang harus dilaksanakan dalam sepanjang masa. Menurutnya Rasulullah SAW. menjelaskan persyaratan suku Quraish untuk menjadi kepala megara ialah dikarenakan pada masa itu suku Quraish mempunyai wibawa serta kekuatan yang disegani di Jazirah Arab karena suku Quraish memiliki ‘as\}abiyyah atau solidaritas kelompok yang kuat. Ikatan solidaritas inilah yang membuat mereka menjadi pemimpin yang kuat pada masa itu. Menurut Ibnu Khaldūn hadis syarat Quraish merupakan pemahaman simbolik karena suku Quraish sebagai simboli pada saat itu hanya suku Quraish yang memiliki kuatnya solidaritas. Namun seiring berjalannya waktu perkembangan serta perubahan situasi dan kondisi tidak menutup untuk suku yang lain yang lebih kuat sehingga jika suku Quraish dalam keadaan tidak lagi suku yang menjadi suku yang paling kuat dan berwibawa maka kepemimpinannya itu dapat berpindah ke suku-suku yang lain yang memiliki kekuatan dan kewibawaan besar serta fanatisme yang lebih kuat. Sebagai mana dalam kitab Muqaddimah nya Ibnu Khaldūn mengatakan" Imam itu berasal dari suku Quraish, atau suku lain yang memiliki kemampuan dan kecakapan sebagaimana yang dimiliki suku Quraish" (Khaldun, 2014, hlm. 193-196)

Dalam kitab Muqaddimah karya Ibnu Khaldūn itu membuka jalan menuju bahasan ilmu-ilmu sosial, Sebagaimana yang tecantum dalam kitab Muqaddimah Ibnu Khaldūn (Khaldun, 2014, hlm. 245).

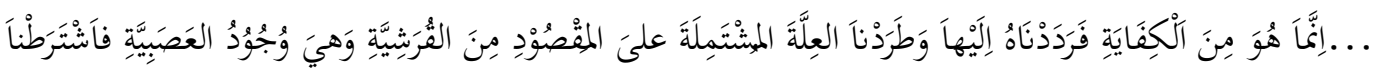

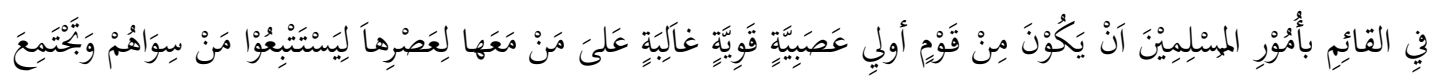

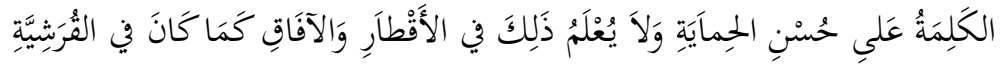

Dengan demikian, maka kami mengembalikan ke khalīfahan pada suku Quraish dan mendasarkan alasan yang menjadi tujuan penetapan suku Quraish sebagai syarat, yaitu adanya fanatisme. Karena itu, kami mensyaratkan orang yang mengurus permasalahan kaum muslimin hendaklah berasal dari bangsa yang memiliki fanatisme kuat dan mampu menguasai fanatismefanatisme pada masanya. Hal ini bertujuan agar mereka mampu menundukkan bangsa lain dan mempersatukan mereka dibawah perlindungan yang baik. Kompetensi ini tidak ditemukan di seluruh pelosok dan wilayah kecuali dalam suku Quraish (Khaldun, 2014, hlm. 340).

\section{Konsep kepemimpian Ibnu Khaldūn Tentang Hadis Quraish}

Menurut Ibnu Khaldūn definisi Khilāfah disamakan dengan imāmah yaitu Al- Khilāfah membawa pemimpin masyarakat sesuai dengan kehendak agama dalam memenuhi kemaslahatan akhiratnya dan dunianya yang kembali kepada ke akhiratan itu, karena hal ihwal keduniawian kembali selurunya menurut Allah untuk kemaslahatan akhirat. Maka kekhilāfahan itu adalah kekhilāfahan dari pemilik syara didalam memelihara agama dan mengendalikan dunia (Dzajuli, 2003, hlm. 56-57).

Ibnu Khaldūn memahami khilāfah itu sama dengan imāmah dimana tujuan akhirnya ialah untuk kembali ke jalan Allah SWT. sistem bentuk negara Menurut Ibnu Khaldūn negara ialah suatu makhluk hidup yang lahir, bertumbuh mekar sampai menjadi tua dan pada akhirnya akan hancur. Negara mempunyai umur seperti halnya makhluk hidup lainnya. Menurut Ibnu Khaldūn bahwa umur umur suatu negara ialah tiga generasi yaitu sekitar 120 tahun, satu generasi dihitung umur seperti orang pada umumnya yaitu sekitar 40 tahun (Khaldun, 2014, hlm. 390). 
Bentuk pemerintahan menurut Ibnu Khaldūn yaitu : bahwa kekuasaan duniawi berada di bawah koridor sistem ke khilāfahan apabila berdasarkan Islam serta ajaran-ajarannya, dan (berdiri sendiri) jika tidak berada di bawah ke khalīfahan karena tidak berdasarkan syariat Islam (Khaldun, 2014, hlm. 390). syarat-syarat kepemimpinan setelah menetapkan pemimpin, maka adapula syarat-syarat yang dapat menduduki jabatan tersebut, adapun kriteria menurut Ibnu Khaldūn ialah: 1) berilmu pengetahuan; 2) berkeadilan; 3) berkompetensi; 4) sehat jasmani dan rohani; 5) memiliki garis keturunan dari suku Quraish.

\section{Analisis Komparasi pemikiran Ibnu Taimiyyah dan Ibnu Khaldūn}

Kedua tokoh fenomenal ini yakni Ibnu Taimiyyah dan Ibnu Khaldūn, mereka ialah sesosok tokoh pemikir Islam yang ide-ide nya menjadi sumber referensi mengenai konsep politik pada zaman nya bahkan sampai saat ini dapat disimpulkan persamaan serta perbedaanya sebagai berikut:

Pertama: Pemikiran Ibnu Taimiyyah dan Ibnu Khaldūn mengenai hadis kepemimpinan Quraish memiliki persamaan mengenai hadis tersebut secara tekstualnya kedua tokoh tersebut menerima bahwa hadis tersebut merupakan hadis yang shahih, kedua tokoh ini memiliki kesimpulan yang sama yaitu memahami hadis kepemimpinan Quraish itu dengan cara kontekstual. Ibnu Taimiyyah menganggap bahwa keturunan Quraish itu boleh di angkat menjadi pemimpin, namun Ibnu Taimiyyah tidak mensyaratkan nya, karena menurut Ibnu Taimiyyah syarat keturunan Quraish bukanlah sebuah keharusan dan Ibnu Taimiyyah menerima kepemimpinan dari kelompok suku yang lain, selama seseorang itu memiliki sifat al-Quwwah dan al-Amannah maka bisa dijadikan seorang pemimpin. Sedangkan menurut Ibnu Khaldūn bahwa kepemimpinan berada ditangan Quraish itu merupakan simbolis, simbol unuk menjadi seorang pemimpin harus seperti suku Quraish yang memiliki kewibawaan, kekuasaan, ketenaran, pemberani, paling kuat dan memiliki solidaritas yang tinggi.

Kedua: Meskipun memiliki kesimpulan yang sama dalam memahami hadis nya itu secara kontekstual, namun berbeda metodologi pemahaman mengenai pemahaman makna hadis kepemimpinan Quraish, Ibnu Taimiyyah memahami hadis tersebut dengan metode us\}ul fikih yakni mas\}lahah mursalah. Berbeda dengan Ibnu Taimiyyah, Ibnu Khaldūn memahami hadis kepempinan Quraish itu menggunakan metode Sosiologis, salah satu pendekatannya ialah așabiyyah.

Ketiga: Pemikiran Ibnu Taimiyyah dan Ibnu Khaldūn mengenai keberadaan pemimpin, mereka bersepakat bahwa pemimpin itu ialah pemecah permaslahan umat. Mendirikan sebuah negara merupakan kewajiban dan keharusan, kedua tokoh muslim ini yakni Ibnu Taimiyyah dan Ibnu Khaldūn pun menyetujui kewajian mendirikan sebuah negara karena tanpa pemimpin negara masyarakat akan mengalami kehancuran yang mengakibatkan berbagai macam ancaman. Namun yang berbeda nya ialah jika Ibnu Taimiyyah berpendapat bahwa kewajiban mendirikan sebuah negara bukan bersumber dari ijma' dikarenakan hal tersebut masih banyak pertentangan dan tidak ada dalil dalam al-Qur'an mengenai bentuk negara pemerintahan sedangkan sebaliknya menurut Ibnu Khaldūn mengangkat seorang pemimpin hukumnya wajib dan mengangkatnya dalam pandangan syariah berdasarkan ijma' dikarenakan para sahabat Rasulullah pada waktu itu segera membai'ah Abū Bakar al-Șidiq menjadi khilāfah mendapatkan kepercayaan serta kesepakatan para sahabat dan tabiin pada masa itu.

keempat: Kualifikasi pemimpin menurut Ibnu Taimiyyah berbeda, jika Ibnu Taimiyyah mensyaratkan syarat pemimpin hanya ada dua yaitu al-Quwwah dan al-Amānah sedangkan Ibnu Khaldūn mencantumkan syarat keturunan Quraish kedalam kualifikasinya terhadap calon kandidat pemmpin.

kelima: Perbedaan pemikiran Ibnu Taimiyyah dan Ibnu Khaldūn mengenai pemimpin, menurut Ibnu Taimiyyah pemikirannya terhadap kemampuan seorang pemimpin tersebut, pemimpin haruslah yang paling terbaik dan paling maslahat untuk yang lain, sedangkan menurut Ibnu Khaldūn memaparkan mengenai pemimpin bahwa pemimpin ialah seorang yang memiliki banyak dukungan dari rakyatnya, serta untuk mendapatkan hal tersebut harus mempunyai asłabiyyah dari rakyatnya. 
Keenam: Perbedaan pemikiran mengenai konsep bentuk negara Ibnu Taimiyyah berpendapat bahwa bentuk negara tidak terdapat dalam Islam serta tidak ada peraturannya yang ada hanya prinsipprisip dalam bernegara saja menampilkan mengenai urgensi kekuasaan dalam menerapkan syariat, karena menurut Ibnu Taimiyyah yang paling utama ialah apapapun bentuk negaranya asalkan menegakkan syariat Islam. Dengan demikian konsep negara menurut Ibnu Taimiyyah ialah menggunakan pemikiran Theokrasi dan Nomokrasi. Theokrasi ialah bentuk pemerintahan yang berada dalam dalam cengkraman tuhan, yaitu pemerintahan yang mengakui tuhan sebagai penguasa mutlak dalam berbagai tatanan pergaulan masyarakat serta menerima wahyu yang telah ditafsirkan oleh para wakil tuhan sebagai dasar negara.

\section{Kesimpulan}

Metode pemahaman Ibnu Taimiyyah dengan metode Ușul Fiqh yakni masłlahah mursalah. Pemahaman Ibnu Taimiyyah mengenai kepemimpinan Quraish menggunakan metodologi mas\}lahah mursalah dikarenakan kualifikasi nya seorang pemimpin ialah dua yakni al-quwwah dan al-amānah, namun karena sulit dijumpai seorang yang memiliki kriteria tersebut, maka ambilah yang lebih maslahat bagi umatnya. Metode pemahaman Ibnu Khaldūn dengan metode Sosiologi, pemahamannya mengenai hadis kepemimpinan Quraish kajian nya menggunakan metode sosial yang terjadi pada masyarakat pada zaman Qurasih menjadi suku yang paling kuat sehingga pada kesimpulannya bahwa hadis kepemimpinan Quraish merupakan simbolis untuk kreteria pemimpin selanjutnya yang seperti kaum Quraish yang memiliki kewibawaan serta solidaritas yang tinggi.

Ibnu Taimiyyah menawarkan konsep kepemimpinan dengan bentuk Theokrasi dan Nomokrasi pemikiran Ibnu Taimiyyah dalam sistem pemerintahan itu bersifat nomokratik bahwa seorang pemerintahan yang berkuasa merupakan hukum yang paling tinggi yang menggantikan segala bentuk kekuasaan yang lain, akan tetapi hakikat dan sekup hukum tersebut membedakan pemerintahan Islam dengan berbagai nomokrasi historis karena memiliki istilah tersendiri.

Ibnu Khaldūn mengusulkan konsep kepemimpinan dalam wuud khilāfah. Ibnu Khaldūn membagi lembaga pemerintahan menjadi dua yakni pemerintahan keagamaan dan lembaga pemerintahan umum, lembaga pemerinatahan secara umum yaitu dari pendiriannya dan bentuk pemerintahannya dan pemikiran beliau mengenai politik bukan hanya terletak pada bentuk negara, akan tetapi bagaimana negara dapat berdiri secara adil dan jujur. sedangkan syarat dapat menduduki jabatan pemimpin, adapun kriteria menurut Ibnu Khaldūn ialah: 1) berilmu pengetahuan; 2) berkeadilan; 3) berkompetensi; 4) sehat jasmani dan rohani; 5) memiliki garis keturunan dari suku Quraish. Dengan demikian, Penelitian ini menyimpulkan bahwa tidak terdapat pertentangan antara Ibnu Taimiyyah dan Ibnu Khaldūn dalam pemahaman hadis tentang kepemimpinan Quraish melainkan sebatas perbedaan metode. Keduanya menggunakan kajian hadis secara mendalam dan kontekstual.

\section{Daftar Pustaka}

Adhayanto, O. (2011). Khilafah dalam sistem pemerintahan Islam. Jurnal Ilmu Politik Dan Ilmu Pemerintahan, 1(1), 80 .

Anjum, O. (2012). Politics, Law, and Community in Islamic Thought: The Taymiyyan Moment. Cambridge University Press.

Ardiansyah, A. (2013). Pengaruh Mazhab Hanbali Dan Pemikiran Ibnu Taimiyah Dalam Paham Salafi. Journal Analytica Islamica, 2(2), 246-261.

Cahyadi, C. (2015). Penafsiran Ayat-ayat tentang Ulil Amri (Studi Komperatif Penafsiran Sayyid Quthb dan Ibnu Taymiyah terhadap QS an-Nisa: 58, 59, dan 83. Skripsi, Program Studi Ilmu al-Qur'an Dan Tafsir, Fakultas Ushuluddin Dan Pemikiran Islam, UIN Sunan Kalijaga.

Dzajuli, H. A. (2003). Figh Siyasyah Implementasi Kemaslahatan Umat dalam Rambu-Rambu Syari'ah. Jakarta: PT Fajar Interpratama Mandiri.

Hamang, M. N. (2010). Sistem Ijtiha dalam Hukum Islam (Metodologi Pembaruan Ibnu Taimiyah). DIKTUM: Jurnal Syariah Dan Hukum, 8(1), 37-46.

Harahap, A. J. (2018). Risywah Dalam Persepektif Hadis. Dirayah, 2(Maret), 109-120. 
Haris, D. M. N., \& Rahim, R. A. A. (2017). Akar Tradisi Politik Sufi Ulama Kalimantan Barat Abad ke-19 dan 20. Ijtimaiyya: Jurnal Pengembangan Masyarakat Islam, 10(1), 39-62.

Husain, M. (t.t.). Islam dalam Perspektif Sosiologi Agama. Titian Ilahi Press.

Ibn Taimiyyah, A. bin 'Abd al-H. bin 'Abd al-Salām. (1999). Siyāsyah Shar'iyyah Etika Politik Islam (M. Rofi', Trans.). Surabaya: Risalah Gusti.

Ibn Taimiyyah, A. bin 'Abd al-H. bin 'Abd al-Salām. (t.t.-a). Al-Siyāsah Shar'iyyah, fì Ișlah Rāi wa al-Ra'iyyah. Beirut: Darr-al-Afaq al-Jadīdah.

Ibn Taimiyyah, A. bin 'Abd al-H. bin 'Abd al-Salām. (t.t.-b). Minhāj al-Sunnah fì naqdi kalām al-Shi'ah wa alQadariyyah (4th ed., Vol. 3). al-Qāhirah: Dār al-Hadīs.

Ibnu Taimiyyah. (t.t.). Minhāj al-Sunnah al Nabawiyah. Riyadh: Maktabah al-Riyadh al-Hadithah.

Ilham, M. (2016). Konsep Așabiyah dalam Pemikiran Politik Ibnu Khaldun. Jurnal Politik Profetik, 4 no. 1.

Iqbal, M. (2016). Fiqh Siyasah Konstekstualisasi Doktrin Politik Islam. Kencana.

Jindan, K. I. (1995). Teori Politik Islam Telaah Kritis Ibnu Taimiyyah tentang Pemerintahan Islam. Surabaya: Risalah Gusti.

Kahmad, D. (2009). Sosiologi Agama. Jakarta: PT Remaja Rosdakarya.

Kayadibi, S. (2018). An Approach On The Role Of Government In The Context Of An Islamic State: Religion And Politics. Journal of Islamic, 3(14x), 78-101.

Khaldun, I. (2014). Muqadimmah Ibn Khaldun (A. Thaha, Trans.). Jakarta: Pustaka Firdaus.

Munawir, S. (t.t.). Islam Dan Tata Negara Ajaran, Sejarah dan Pemikiran. Jakarta: UI Press.

Muzaffari, M. (1994). Kekuasaan Dalam Islam. Jakarta: Pustaka Panjimas.

Pemikiran Politik Sunni, Syiah, Khawarij dan Mu'tazilah - Kompasiana.com. (t.t.). Retrieved September 22, 2020, from https://www.kompasiana.com/lismanto/55124565a33311e656ba8156/pemikiran-politik-sunni-syiahkhawarij-dan-mu-tazilah

Pulungan, J. S. (t.t.). Figh Siyasah Ajaran, Sejarah dan Pemikiran. Jakarta: PT Raja Grafindo Persada.

Pulungan, S. (1999). Fikih Siyasah. Jakarta: PT Raja Grafindo.

Purwanto, E. (2018). Kritik Kepemimpinan Terhadap Penguasa Perspektif Ibnu Taimiyah Dan Aktualisasinya Di Indonesia. Putra Z, H. (2018). Pemahaman Hadis Kepemimpinan Quraisy. Universitas Syarif Hidyatullah, Jakarta.

Rangkuti, A. (2017). Konsep keadilan dalam perspektif Islam. TAZKIYA, 6(1).

Sholihin, R. (2008). Referensi Islam dalam Memilih Pemimpin. KONSTITUSI Jurnal, 1(1), 70.

Sucipto, S. (2013). Pembaharuan hukum Islam (Studi terhadap Pemikiran Hukum Ibnu Taimiyah). ASAS, 5(1).

Sumaryadi, I. N. (2010). Sosiologi Pemerintahan dari Perspektif Pelayanan, Pemberdayaan, Interaksi, dan Sistem Kepemimpinan Pemerintahan Indonesia. Bogor: Ghalia Indonesia.

Swito, F. (2011). Peran Ibnu Taimiyah dalam pemurnian Aqidah Islamiyah.

Syukkur, A. (2019). Pemikiran Dan Metode Tafsir Ibnu Taimiyah Dalam Tafsīr Al-Kabī R. El-Furqania: Jurnal Ushuluddin Dan Ilmu-Ilmu Keislaman, 5(01), 20-36.

Triwijaya, A. R. (2018). Analisis Perbandingan Corak Pemikiran Etika Politik Ibnu Taimiyah dan Ibnu Khaldun (Skripsi). Universitas Raden Intan, Lampung.

Ulum, H. (2012). Studi Pemahaman Hadis Ibnu Taimiyyah tentang Hadis Kepemimpinan Quraisy. Skripsi Program Sarjana Institut Agama Islam Negeri Walisongo, Semarang.

Yunus, N. R. (2015). Penerapan Syariat Islam terhadap Peraturan Daerah dalam Sistem Hukum Nasional Indonesi. Hunafa: Jurnal Studia Islamika, 12(2), 253-279.

Zarkasyi, A. F. (2013). Tajdid dan Modernisasi Pemikiran Islam. TSAQAFAH, 9(2), 395-418.

Zulbaidah. (2016). Ushul Figh 1 Kaidah-Kaidah Tasyri'iyah. Bogor: Ghalia Indonesia.

(C) 2020 by the authors. It was submitted for possible open access publication under the terms and conditions of the Creative Commons Attribution (CC BY SA) license (https://creativecommons.org/licenses/by-sa/3.0/). 